Journal Wetenskap Health

\title{
Erderly Behavior Factors Affecting Compliance of Hypertension Patients at Mitra Medan Public Hospital
}

\author{
Lingse Elsina Sianipar ${ }^{1}$, Razia Begum Suroyo ${ }^{2}$, Muhammad Badiran ${ }^{3}$, Yuniati ${ }^{4}$ \\ Corresponding Email: lingseelsina2009@gmail.com \\ ${ }^{1}$ Public Health Master Student of the Helvetia Institute of Health, Indonesia \\ ${ }^{2}$ Master of Public Health Lecturer Helvetia Institute of Health, Indonesia \\ ${ }^{3}$ Masters in Public Health, Helvetia Institute of Health, Indonesia
}

\begin{abstract}
The prevalence of hypertension continues to increase from year to year, especially in the elderly. The high number of cases of hypertension is thought to be due to a lack of compliance in complying with the recommendations of health workers such as carrying out routine checks (blood pressure control), taking medication regularly, adopting a low-salt diet, and doing regular exercise. The purpose of this study was to analyze the behavioral factors of the elderly that influenced hypertension patient compliance.The results showed that the factors that influenced the compliance of hypertensive patients at Mitra Medika General Hospital Medan were knowledge, motivation, insurance participation, and family support. Meanwhile, the variables that did not influence were age, gender, health facilities, distance, and support for health workers. The conclusion of this research is that knowledge, motivation, insurance participation and family support affect the compliance of hypertensive patients.
\end{abstract}

Keywords: Behavior, Elderly, Compliance, Hypertension

\section{Introduction}

Hypertension is a chronic medical condition in which the blood pressure (BP) rises above the normal agreed BP. BP is formed from the interaction between blood flow and peripheral vascular resistance, blood pressure increases and reaches a peak when blood flow decreases as in diastole. Thus, two types of BP were obtained, namely systolic BP (normal $\pm 120 \mathrm{mmHg}$ ) and diastolic BP (normal $\pm 80 \mathrm{mmHg}$ ). The difference between systolic and diastolic pressure is called pulse pressure (Pulse pressure, normal $\pm 40 \mathrm{mmHg}$ ) (Kabo, 2018).

Hypertension or "high blood pressure" disease is a condition when a person experiences a slow or sudden (acute) increase in blood pressure. Persistent hypertension (decreased high blood pressure) is a risk factor for stroke, coronary heart disease (CHD). Heart failure, kidney failure, and arterial aneurysms (blood vessel disease). Although the increase in blood is relatively small, it can reduce life expectancy (Agoes, 2018). Elderly in the process of becoming older with age reaching 60 years and over. The elderly will experience physical, mental and social deterioration. One example of physical deterioration in the elderly is the vulnerability of the elderly to diseases, especially degenerative diseases, degenerative diseases commonly suffered by the elderly, one of which is hypertension.

Based on the results of the initial survey at Mitra Medika General Hospital Medan for one week, that the visit of patients suffering from hypertension. When viewed from data from Mitra Medika Hospital, the number of cases of outpatient hypertension patients for the last five years, namely 270 in 2015, 690 people in 2016, and in 2017 the number of visits 1,813 people, in 
2018 the number of hypertension visits increased to 2,286 people, in 2019 the number of visits was 1,737 based on the description of the data it can be seen that there was an unstable increase in the number of visits of hypertension sufferers to the hospital every year (RSU Mitra Medika, 2020).

Meanwhile, from the results of the interview, there were 10 elderly patients who suffered from hypertension at the Mitra Medika General Hospital, Medan. They are all aged 60 years and over, as many as 6 of them are female, and 4 are male. Work as an entrepreneur, laborer and housewife. Educated from Elementary School, Junior High School, Senior High School, and Bachelor Degree. As many as 2 people said that they could not come for treatment regularly because they often forgot, 3 people said they did not take them to Mitra Medika General Hospital Medan, 1 person said they were lazy to come to the hospital because they were far from home, so they went to the nearest doctor's practice clinic, and 4 people said the patient was tired of taking medication continuously. World Health Organization (WHO) data in 2015 shows that one billion people in the world suffer from hypertension, 2/3 of whom are in low to medium income developing countries. The prevalence of hypertension will continue to increase sharply and it is predicted that by 2025 as many as $29 \%$ of adults worldwide are affected by hypertension. Hypertension has resulted in the death of around 8 million people every year, of which 1.5 million deaths occur in Southeast Asia, where 1/3 of the population is suffering from hypertension, so it can cause an increase in the burden of health costs (WHO, 2018).

One in three adults in the United States has hypertension, which generally causes no complaints, despite years of experience. During this time, damage occurs to the heart, kidneys, blood vessels, and other parts of the body (4). The American Heart Association (AHA) and the American College of Cardiology (ACC) on November 13, 2017, issued the latest hypertension guidelines. The guidelines for hypertension mean that hypertension is determined if the systolic blood pressure is $\geq 130 \mathrm{mmHg}$ or the diastolic blood pressure is $\geq 80 \mathrm{mmHg}$. This 10-point drop in systolic and diastolic blood pressure causes 103 million people in the United States to experience hypertension (Nasution, 2017).

The Ministry of Health in order to support the peak event of the 2016 National Elderly Day commemoration is the launch of the RAN Action Plan which can be used as a legal umbrella for all regions to accelerate the development of elderly health programs because it was issued as Permenkes Number 25 of 2016 concerning the National Action Plan (RAN) for Elderly Health 2016-2019 years. Elderly is someone who reaches the age of 60 years and over, based on Law Number 13 of 1998 concerning Elderly Welfare. Globally, the elderly population is predicted to continue to increase. The population of elderly people in Indonesia is predicted to increase higher than the population of elderly people in the world after 2100 (Kemenkes RI, 2014).

The national hypertension prevalence based on Riskesdas 2013 was $25.8 \%$, the highest was in the Bangka Belitung Islands (30.9\%), while the lowest was in Papua (16.8\%). Based on these data, from $25.8 \%$ of people who have hypertension only $1 / 3$ are diagnosed, the remaining $2 / 3$ are undiagnosed (Analisadaily, 2018). The data shows that only $0.7 \%$ of people diagnosed with high blood pressure take hypertension medication. This shows that most hypertension sufferers do not realize that they are suffering from hypertension or are receiving treatment (Nasution, 2017).

The Indonesian government realizes that hypertension, which is included in NonCommunicable Diseases (PTM), is a health problem and a cause of death which is a global 
threat to economic growth in Indonesia. Early detection is an effort to reduce the prevalence of non-communicable diseases (PTM). The government policy regarding Integrated Guidance Posts (Posbindu) is expected to be able to mobilize all lines of society to conduct early detection based on public health efforts. The types of Posbindu PTM activities include: Measuring blood pressure; Perform blood sugar checks; Take measurements of blood fat levels (total cholesterol and triglycerides); Perform a simple pulmonary function check (Peakflowmeter). Hypertension sufferers can make early detection at Posbindu by measuring blood pressure regularly (Kemenkes RI, 2014)

The increasing number of elderly in Indonesia gives special attention to the elderly who are experiencing an aging process. Problems Seeing the phenomenon above, it is very important for the elderly to carry out routine blood pressure control and control taking medication. associated with hypertension in the elderly with a history of high blood pressure in the family, being overweight followed by a lack of exercise. hypertension needs lifestyle modification such as: adjusting the diet by limiting the intake of salt, fat, alcohol, stopping smoking, and controlling body weight. Until now, there have been many national and international publications that examine the diagnosis and therapy of hypertension.

Based on data from the North Sumatra Provincial Health Office, it was recorded that 50,162 people suffer from hypertension. In fact, this number is not complete because there are still 10 districts / cities, namely Medan, Deliserdang, South Labuhan Batu, Tanjung Balai, North Tapanuli, Samosir, South Tapanuli, Nias and North Nias have not submitted data to the North Sumatra Health Office. In these data, it was noted that the most people suffering from hypertension were women with a total of 27,021. For those who suffer from hypertension the most are those over 55 years with a total of 22,618, then 18 to 44 years with a total of 14,984 and ages 45 to 55 years with a total of 12,560. Dairi with the number of 5652, Asahan with the number of 5421 and Pematang Siantar with the number of 4055 people. The high cases of hypertension are thought to be due to a lack of compliance in complying with the recommendations of health workers such as carrying out routine checks (blood pressure control), taking medication regularly, doing a low salt diet, and doing regular exercise (Kemenkes RI, 2014).

Adherence describes the extent to which the patient's behavior to implement the rules in treatment and education provided by health workers (Hairunisa, 2014). One of the frequent increases in blood pressure in the elderly is due to low / poor adherence in the elderly. Elderly compliance is a form of health behavior. According to Green, in Notoatmodjo states that a person's behavior is influenced by predisposing factors such as knowledge, attitudes, beliefs, and values regarding the person's motivation to act; demographic factors include age, gender, education, number of children, and others; Enabling factors, namely health facilities, distance, ownership of health insurance, quality of service, facilities and infrastructure that support or facilitate the occurrence of a person's behavior; and reinforcing factors such as family support, health worker support, and others (Notoatmodjo, 2016).

\section{Methods}

This research used a Mix Method research method with quantitative and qualitative approaches with an explanatory sequential approach applied by collecting and analyzing quantitative data in the first stage followed by the collection and analysis of qualitative data which was built on the initial quantitative results. Population is a generalization area consisting of objects and subjects that have certain qualities and characteristics that the researcher 
determines to study and draw conclusions. The population of this study were 360 hypertensive patients who were treated at Mitra Medika Hospital. Based on the mix method research flow above, the initial stage will be a quantitative method, namely conducting a survey using a questionnaire to obtain information about knowledge, motivation, eating habits, stress, family support and support from health workers in hypertension patients who are treated at Mitra Medika Hospital. Field. Furthermore, the material deepening was carried out using qualitative methods, namely interviews with selected informants to explore in depth the dominant variables that had an effect on the compliance of hypertensive patients in treatment and to find out which variables were not dominant influencing the compliance of hypertensive patients. can affect hypertension patient compliance. The study was conducted at the Mitra Medika Hospital, Medan

\section{Results and Discussion}

\section{Bivariate Analysis}

\section{Relationship between Age and Compliance with Hypertension Patients}

Table 1.Age Relationship with Hypertension Patient Compliance at Mitra Medika General Hospital, Medan, 2020

\begin{tabular}{|c|c|c|c|c|c|c|c|c|}
\hline \multirow{3}{*}{ No } & \multirow{3}{*}{ Age } & \multicolumn{4}{|c|}{$\begin{array}{c}\text { Hypertension Patient } \\
\text { Compliance }\end{array}$} & \multirow{2}{*}{\multicolumn{2}{|c|}{ Amount }} & \multirow{3}{*}{$\begin{array}{c}p- \\
\text { value }\end{array}$} \\
\hline & & \multicolumn{2}{|c|}{ Low } & \multicolumn{2}{|c|}{ High } & & & \\
\hline & & $\mathbf{f}$ & $\%$ & $\mathbf{f}$ & $\%$ & $\mathbf{f}$ & $\%$ & \\
\hline 1 & $60-70$ yeras & 32 & 41,0 & 25 & 32,1 & 57 & 73,1 & \multirow{3}{*}{0,802} \\
\hline 2 & $71-90$ yeras & 11 & 14,1 & 10 & 12,8 & 21 & 26,9 & \\
\hline & Total & 43 & 55,1 & 35 & 44,9 & 78 & 100,0 & \\
\hline
\end{tabular}

Based on table 1. it shows that of the 57 respondents aged 60-70 years, the majority of them had low compliance as many as 32 people (41.0\%). Of the 21 respondents aged 71-90 years, the majority of the obedience was low as many as 11 people $(14.1 \%)$. The results of the bivariate test using Chi-Square obtained a p-value of 0.802>0.05, meaning that there is no relationship between age and compliance with hypertension patients at Mitra Medika General Hospital Medan in 2020.

\section{Relationship between Gender and Hypertension Patient Compliance}

Table 2.The Relationship between Gender and Compliance with Hypertension Patients at Mitra Medika General Hospital, Medan, 2020

\begin{tabular}{|c|c|c|c|c|c|c|c|c|}
\hline \multirow{3}{*}{ No } & \multirow{3}{*}{ Sex } & \multicolumn{4}{|c|}{$\begin{array}{c}\text { Hypertension Patient } \\
\text { Compliance }\end{array}$} & \multirow{2}{*}{\multicolumn{2}{|c|}{ Amount }} & \multirow{3}{*}{$\begin{array}{c}p- \\
\text { value }\end{array}$} \\
\hline & & \multicolumn{2}{|c|}{ Low } & \multicolumn{2}{|c|}{ High } & & & \\
\hline & & $\mathbf{f}$ & $\%$ & $\mathbf{F}$ & $\%$ & $\mathbf{f}$ & $\%$ & \\
\hline 1 & Female & 18 & 23,1 & 23 & 29,5 & 41 & 52,6 & \multirow{3}{*}{0,030} \\
\hline 2 & Male & 25 & 32,0 & 12 & 15,4 & 37 & 47,4 & \\
\hline & Total & 43 & 55,1 & 35 & 44,9 & 78 & 100,0 & \\
\hline
\end{tabular}

Based on table 2, it shows that of the 41 respondents who were female, the majority had high compliance as many as 23 people $(29.5 \%)$. Of the 37 respondents who were male, the majority had low compliance as many as 25 people (32.0\%). The results of the bivariate test 
using Chi-Square obtained a p-value of $0.030<0.05$, meaning that there is a sex relationship with hypertension patient compliance at Mitra Medika General Hospital Medan in 2020.

\section{Relationship between Knowledge and Hypertension Patient Compliance}

Table 3. Knowledge Relationship with Hypertension Patient Compliance at Mitra Medika General Hospital, Medan, 2020

\begin{tabular}{|c|c|c|c|c|c|c|c|c|}
\hline \multirow{3}{*}{ No } & \multirow{3}{*}{ Knowledge } & \multicolumn{4}{|c|}{$\begin{array}{c}\text { Hypertension Patient } \\
\text { Compliance }\end{array}$} & \multirow{2}{*}{\multicolumn{2}{|c|}{ Amount }} & \multirow{3}{*}{$\begin{array}{c}p- \\
\text { value }\end{array}$} \\
\hline & & \multicolumn{2}{|c|}{ Low } & \multicolumn{2}{|c|}{ High } & & & \\
\hline & & $\mathbf{f}$ & $\%$ & $\mathbf{F}$ & $\%$ & $\mathbf{f}$ & $\%$ & \\
\hline 1 & Less & 28 & 35,9 & 12 & 15,4 & 40 & 51,3 & \multirow{3}{*}{0,012} \\
\hline 2 & Good & 15 & 19,2 & 23 & 29,5 & 38 & 48,7 & \\
\hline & Total & 43 & 55,1 & 35 & 44,9 & 78 & 100,0 & \\
\hline
\end{tabular}

Based on table 3, it shows that of the 40 respondents who had less knowledge, the majority had low compliance as many as 28 people (35.9\%). Of the 38 respondents who had good knowledge, the majority had high compliance as many as 23 people $(29.5 \%)$. The results of the bivariate test using Chi-Square obtained a p-value of $0.012<0.05$, which means that there is a relationship between knowledge and compliance with hypertensive patients at Mitra Medika General Hospital Medan in 2020.

\section{Relationship between Motivation and Hypertension Patient Compliance}

Table 4. The Relationship between Motivation and Hypertension Patient Compliance at Mitra Medika General Hospital, Medan, 2020

\begin{tabular}{|c|c|c|c|c|c|c|c|c|}
\hline \multirow{3}{*}{ No } & \multirow{3}{*}{ Motivation } & \multicolumn{4}{|c|}{$\begin{array}{c}\text { Hypertension Patient } \\
\text { Compliance }\end{array}$} & \multirow{2}{*}{\multicolumn{2}{|c|}{ Amount }} & \multirow{3}{*}{$\begin{array}{c}p- \\
\text { value }\end{array}$} \\
\hline & & \multicolumn{2}{|c|}{ Low } & \multicolumn{2}{|c|}{ High } & & & \\
\hline & & $\mathbf{f}$ & $\%$ & $\mathbf{F}$ & $\%$ & $\mathbf{f}$ & $\%$ & \\
\hline 1 & Low & 27 & 34,6 & 10 & 12,8 & 37 & 47,4 & \multirow{3}{*}{0,003} \\
\hline 2 & High & 16 & 20,5 & 25 & 32,1 & 41 & 52,6 & \\
\hline & Total & 43 & 55,1 & 35 & 44,9 & 78 & 100,0 & \\
\hline
\end{tabular}

Based on table 4, shows that of the 37 respondents with low motivation, the majority of them had low compliance as many as 27 people (34.6\%). Of the 41 respondents with high motivation, the majority of them had high compliance as many as 25 people $(32.1 \%)$. The results of the bivariate test analysis using Chi-Square obtained a p-value of $0.003<0.05$, which means that there is a relationship between motivation and compliance with hypertensive patients at Mitra Medika General Hospital Medan in 2020.

\section{Relationship between Health Facilities and Hypertension Patient Compliance}

Table 5. Relationship between Health Facilities and Compliance with Hypertension Patients at Mitra Medika General Hospital, Medan, 2020

\begin{tabular}{|c|c|c|c|c|c|c|c|c|}
\hline \multirow{3}{*}{ No } & \multirow{3}{*}{ Health Facility } & \multicolumn{4}{|c|}{$\begin{array}{c}\text { Hypertension Patient } \\
\text { Compliance }\end{array}$} & \multirow{2}{*}{\multicolumn{2}{|c|}{ Amount }} & \multirow{3}{*}{$\begin{array}{c}p- \\
\text { value }\end{array}$} \\
\hline & & \multicolumn{2}{|c|}{ Low } & \multicolumn{2}{|c|}{ High } & & & \\
\hline & & $\mathbf{f}$ & $\%$ & $\mathbf{F}$ & $\%$ & $\mathbf{f}$ & $\%$ & \\
\hline 1 & Inadequate & 13 & 16,7 & 15 & 19,2 & 28 & 35,9 & 0,343 \\
\hline
\end{tabular}




\begin{tabular}{|c|c|c|c|c|c|c|c|c|}
\hline 2 & Adequate & 30 & 38,5 & 20 & 25,6 & 50 & 64,1 & \\
\cline { 1 - 6 } & Total & $\mathbf{4 3}$ & $\mathbf{5 5 , 1}$ & $\mathbf{3 5}$ & $\mathbf{4 4 , 9}$ & $\mathbf{7 8}$ & $\mathbf{1 0 0 , 0}$ & \\
\hline
\end{tabular}

Based on table 5, shows that of the 28 respondents who stated that health facilities were inadequate, the majority had high compliance as many as 15 people $(19.2 \%)$, and respondents with low compliance were 13 people $(16.7 \%)$. Of the 50 respondents who stated that health facilities were adequate, the majority had low compliance as many as 30 people $(38.5 \%)$, and respondents with high compliance were 20 people $(25.6 \%)$. The results of the bivariate test analysis using Chi-Square obtained a p-value of 0.343>0.05, meaning that there is no relationship between health facilities and hypertension patient compliance at Mitra Medika General Hospital Medan in 2020.

\section{Relationship of Distance with Hypertension Patient Compliance}

Table 6. Relation of Distance with Hypertension Patient Compliance at Mitra Medika General Hospital, Medan, 2020

\begin{tabular}{|c|c|c|c|c|c|c|c|c|}
\hline \multirow{3}{*}{ No } & \multirow{3}{*}{ Distance } & \multicolumn{4}{|c|}{$\begin{array}{c}\text { Hypertension Patient } \\
\text { Compliance }\end{array}$} & \multirow{2}{*}{\multicolumn{2}{|c|}{ Amount }} & \multirow{3}{*}{$\begin{array}{c}p- \\
\text { value }\end{array}$} \\
\hline & & \multicolumn{2}{|c|}{ Low } & \multicolumn{2}{|c|}{ High } & & & \\
\hline & & $\mathbf{f}$ & $\%$ & $\mathbf{F}$ & $\%$ & $\mathbf{f}$ & $\%$ & \\
\hline 1 & Hard to reach & 19 & 24,4 & 11 & 14,1 & 30 & 38,5 & \multirow{3}{*}{0,350} \\
\hline 2 & Reachable & 24 & 30,8 & 24 & 30,8 & 48 & 61,5 & \\
\hline & Total & 43 & 55,1 & 35 & 44,9 & 78 & 100,0 & \\
\hline
\end{tabular}

Based on table 6 , it shows that of the 30 respondents who stated that the distance to the hospital was difficult to reach, the majority had low compliance as many as 19 people $(24.4 \%)$, and respondents with high compliance were 11 people (14.1\%). Of the 48 respondents who stated that the distance to the hospital was easy to reach, 24 people had low compliance (30.8\%), as well as 24 respondents with high compliance $(30.8 \%)$. The results of the bivariate test analysis using Chi-Square obtained a p-value of $0.350>0.05$, meaning that there is no relationship between distance and compliance with hypertensive patients at Mitra Medika General Hospital Medan in 2020.

\section{Relationship between insurance participation and hypertension patient compliance}

Table 7. The Relationship between Insurance Participation and Compliance with Hypertension Patients at Mitra Medika General Hospital, Medan, 2020

\begin{tabular}{|c|c|c|c|c|c|c|c|c|}
\hline \multirow{3}{*}{ No } & \multirow{3}{*}{$\begin{array}{c}\text { Insurance } \\
\text { Participation }\end{array}$} & \multicolumn{4}{|c|}{$\begin{array}{c}\text { Hypertension Patient } \\
\text { Compliance }\end{array}$} & \multirow{2}{*}{\multicolumn{2}{|c|}{ Amount }} & \multirow{3}{*}{$\begin{array}{c}p- \\
\text { value }\end{array}$} \\
\hline & & \multicolumn{2}{|c|}{ Low } & \multicolumn{2}{|c|}{ High } & & & \\
\hline & & $\mathbf{f}$ & $\%$ & $\mathbf{F}$ & $\%$ & $\mathbf{f}$ & $\%$ & \\
\hline 1 & Don't participate & 13 & 16,7 & 3 & 3,8 & 16 & 20,5 & \multirow{3}{*}{0,024} \\
\hline 2 & Participate & 30 & 38,4 & 32 & 41,1 & 62 & 79,5 & \\
\hline & Total & 43 & 55,1 & 35 & 44,9 & 78 & 100,0 & \\
\hline
\end{tabular}

Based on table 7, it shows that of the 16 respondents who did not participate in insurance the majority had low compliance as many as 13 people (16.7\%). Of the 62 respondents who participated in insurance, the majority had high compliance as many as 32 people $(41.1 \%)$. The results of the bivariate test analysis using Chi-Square obtained a p-value of $0.024<0.05$, which 
means that there is a relationship between insurance participation and compliance with hypertensive patients at Mitra Medika General Hospital Medan in 2020.

\section{Relationship between Family Support and Hypertension Patient Compliance}

Table 8. The Relationship between Family Support and Hypertension Patient Compliance at Mitra Medika General Hospital, Medan, 2020

\begin{tabular}{|c|c|c|c|c|c|c|c|c|}
\hline \multirow{3}{*}{ No } & \multirow{3}{*}{ Family support } & \multicolumn{4}{|c|}{$\begin{array}{c}\text { Hypertension Patient } \\
\text { Compliance }\end{array}$} & \multirow{2}{*}{\multicolumn{2}{|c|}{ Amount }} & \multirow{3}{*}{$\begin{array}{c}p- \\
\text { value }\end{array}$} \\
\hline & & \multicolumn{2}{|c|}{ Low } & \multicolumn{2}{|c|}{ High } & & & \\
\hline & & $\mathbf{f}$ & $\%$ & $\mathbf{F}$ & $\%$ & $\mathbf{f}$ & $\%$ & \\
\hline 1 & Less supportive & 22 & 28,2 & 7 & 9,0 & 29 & 37,2 & \multirow{3}{*}{0,005} \\
\hline 2 & Supportive & 21 & 26,9 & 28 & 35,9 & 49 & 62,8 & \\
\hline & Total & 43 & 55,1 & 35 & 44,9 & 78 & 100,0 & \\
\hline
\end{tabular}

Based on table 8. it shows that of the 29 respondents whose families were less supportive, the majority had low compliance as many as 22 people (28.2\%). Of the 49 respondents whose families supported the majority of high compliance, there were 28 people (35.9\%). The results of the bivariate analysis using Chi-Square obtained a p-value of $0.005<0.05$, which means that there is a relationship between family support and compliance with hypertensive patients at Mitra Medika General Hospital Medan in 2020.

\section{Relationship between Health Care Worker Support and Hypertension Patient Compliance}

Table 9. The Relationship between Health Care Workers' Support and Hypertension Patient Compliance at Mitra Medika General Hospital, Medan, 2020

\begin{tabular}{|c|c|c|c|c|c|c|c|c|}
\hline \multirow{3}{*}{ No } & \multirow{3}{*}{$\begin{array}{l}\text { Health Officer } \\
\text { Support }\end{array}$} & \multicolumn{4}{|c|}{$\begin{array}{c}\text { Hypertension Patient } \\
\text { Compliance }\end{array}$} & \multirow{2}{*}{\multicolumn{2}{|c|}{ Amount }} & \multirow{3}{*}{$\begin{array}{c}p- \\
\text { value }\end{array}$} \\
\hline & & \multicolumn{2}{|c|}{ Low } & \multicolumn{2}{|c|}{ Low } & & & \\
\hline & & $\mathbf{f}$ & $\%$ & $\mathbf{f}$ & $\%$ & $\mathbf{f}$ & $\%$ & \\
\hline 1 & Less supportive & 25 & 32,1 & 11 & 14,1 & 36 & 46,2 & \multirow{3}{*}{0,023} \\
\hline 2 & Supportive & 18 & 23,0 & 24 & 30,8 & 42 & 53,8 & \\
\hline & Total & 43 & 55,1 & 35 & 44,9 & 78 & 100,0 & \\
\hline
\end{tabular}

Based on table 4.20, it shows that of the 36 respondents who stated that health workers were less supportive of the majority, 25 people had low compliance $(32.1 \%)$. Of the 42 respondents who stated that health workers supported the majority of high compliance, there were 24 people $(30.8 \%)$. The results of the bivariate test using Chi-Square obtained a p-value of $0.023<0.05$, which means that there is a relationship between support from health workers and compliance with hypertension patients at Mitra Medika General Hospital Medan in 2020.

\section{Multivariate Analysis}

Table 10. Multiple Logistic Regression Test Model Candidates

\begin{tabular}{|l|c|c|}
\hline \multicolumn{1}{|c|}{ Variable } & p & Description \\
\hline Gender & 0,043 & Candidate Model \\
Knowledge & 0,012 & Candidate Model \\
Motivation & 0,003 & Candidate Model \\
Insurance participation & 0,024 & Candidate Model \\
Family support & 0,005 & Candidate Model \\
\hline
\end{tabular}




\begin{tabular}{|l|c|c|}
\hline Health worker support & 0,023 & Candidate Model \\
\hline Age & 0,802 & Not a Model Candidate \\
Medical facility & 0,343 & Not a Model Candidate \\
Distance & 0,350 & Not a Model Candidate \\
\hline
\end{tabular}

Furthermore, testing with multiple logistic regression simultaneously with the forward conditional method was carried out to identify the factors most influencing the compliance of hypertensive patients. The forward conditional method is to enter one by one the variables from the results of correlating variables and meet the criteria for statistical significance to enter the model, until all variables that meet these criteria are entered into the model. The variables that are entered first are those that have the largest partial correlation with the dependent variable and which meet certain criteria to enter the model. The result of multiple logistic regression test shows that of the 6 variables as candidate models, there are 4 variables that influence hypertension compliance, namely knowledge, motivation, insurance participation and family support. Details can be seen in the following table.

Table 11. Dominant Factors Affecting Compliance of Hypertension Patients at Mitra Medika Tahn General Hospital 2020

\begin{tabular}{|l|c|c|c|c|}
\hline \multicolumn{1}{|c|}{ Variable } & B & Sig. & $\begin{array}{c}\operatorname{Exp}(\mathbf{B}) / \\
\text { OR }\end{array}$ & $\begin{array}{c}\mathbf{9 5 \% C I ~ f o r ~} \\
\mathbf{E x p}(\mathbf{B})\end{array}$ \\
\hline Knowledge & 1.279 & 0,025 & 3,594 & $1,215-10,628$ \\
Motivation & 1.206 & 0,029 & 3,339 & $1,133-9,843$ \\
Insurance participation & 1.735 & 0,022 & 5,667 & $1,278-25,130$ \\
Family support & 1.148 & 0,049 & 3,152 & $1,002-9,918$ \\
Constant & -3.663 & 0,000 & & \\
\hline
\end{tabular}

The dominant variable or the variable that has the greatest influence on the compliance of hypertensive patients in this study is the insurance participation variable which has a value of $\operatorname{Exp}(\mathrm{B}) / \mathrm{OR}=5.667$, which means that the elderly who participate in insurance have a high chance of adherence to hypertension treatment by 5.6 times higher than the elderly. who do not participate in insurance. The knowledge variable has a value of $\operatorname{Exp}(\mathrm{B}) / \mathrm{OR}=3.594$, meaning that the elderly with good knowledge have a high chance of adherence to hypertension treatment by 3.5 times higher than the elderly with poor knowledge.

The motivation variable, the value of $\operatorname{Exp}(\mathrm{B}) / \mathrm{OR}=3.339$, means that the elderly with high motivation have a high chance of adherence to hypertension treatment, 3.3 times higher than the elderly with low motivation. The family support variable has a value of Exp (B) / OR $=3.152$, meaning that the elderly whose families are supportive, have a high chance of adherence to hypertension treatment by 3.1 times higher than the elderly whose families are less supportive. Based on the results of the multiple logistic regression test, it also shows that the variables that do not affect the compliance of hypertensive patients because it has a significant value $>0.05$ are the variables of gender and health worker support. Details can be seen in the following table.

\section{Hypertension Patient Compliance}

The results showed that the compliance of hypertensive patients who came for treatment at Mitra Medika General Hospital Medan was mostly in the low category (55.1\%), while the obedient ones were $44.9 \%$. Adherence to treatment is often low. A survey conducted by Khanam in Bangladesh in 2014, showed 26\% non-adherence to treatment in a sample of 29,960 
men and women aged 25 years and over (Khanam, 2014). The results of this study are in line with Purnawan's research in the Payangan Health Center work area, Gianyar-Bali in May-June 2015, showing that from a total of 242 respondents involved in the study, it was known that $41.32 \%$ obeyed and $58.68 \%$ did not comply with treatment (Purnawan, 2015). The results of research conducted by Dewi at Puskesmas Dau Malang Regency in 2018, the results showed that compliance with the treatment of most respondents was categorized as less obedient, namely 76.67\% (Dewi et al., 2018). The results of a study conducted by the State with the title Relationship of Knowledge Levels about Hypertension to Patient Compliance for Blood Pressure Control in 2018 that from the univariate analysis showed that most respondents' compliance in controlling blood pressure was in the moderate category $(82.7 \%)$ (Negara \& Jiryantini, 2017).

Compliance (obedience) as the level of the patient to carry out the treatment methods and behavior suggested by a doctor or other person (Arumwardhani, 2017). Adherence is defined as the patient's positive behavior in achieving therapeutic goals. The treatment program can be made as simple as possible and the client appears to be active in making a treatment program (therapy). The regularity of patients with hypertension to carry out routine examinations or controls is influenced by their health. Complaints suffered by people with hypertension will make him more active in visits to health workers. Adherence for people with hypertension, especially compliance in maintaining normal blood pressure, is an important factor in the management of care for hypertensive patients (Niven, 2014). For people with hypertension, adherence to treatment is one of the factors that determine the success of therapy (WHO, 2017).

Hypertension treatment aims to reduce complications of hypertension. In order to avoid complications of hypertension, it is necessary to comply with the rules for taking the medication recommended by the doctor with the right dosage, namely not to increase the amount of medicine without the doctor's knowledge. Be on time, don't forget to take your medicine. In order to always be awake from the factor of forgetting, then take the medicine just before routine activities that are never forgotten every day. Realize that forgetting to take medication means that the continuity of the drug to protect the organs will weaken (Sutanto, 2016).

\section{Effect of Age on Compliance with Hypertension Patients}

The results of the study on the bivariate test analysis showed that age had no effect on hypertension patient compliance at Mitra Medika Hospital Medan, $\mathrm{p}=0.802>0.05$. Hazwan's research shows that based on the age group, it was found that $80.0 \%$ of respondents were in the $\geq 50$ years age group, and $20.0 \%$ in the $<50$ years age group. The oldest age of respondents with hypertension was 86 years, while the youngest was 40 years old. According to the age group, the age group $\leq 50$ years has lower adherence than the age group $>50$ years (Hazwan \& Pinatih, 2017).

Kionowati's research in Kendal Regency found that the highest frequency of respondents was in the elderly age group, namely $61.8 \%$. Increased blood pressure in hypertensive patients with increasing age. This is caused by changes in the structure of the blood vessels, so that the lumen becomes narrower and the walls of the blood vessels become stiff, as a result of which there is an increase in blood pressure (Kionowati. et al., 2018).

In contrast to Firiana's research, it was found that out of 98 respondents with young adulthood, as many as 89 people $(90.8 \%$ ) had adherence and as many as 9 people $(9.2 \%)$ had non-compliance. And from 12 respondents with final age, there were 6 people (50\%) who had 
good adherence and 6 people $(50 \%)$ had non-compliance. After the statistical test was carried out with the chi-square test, the results obtained were $p=0.000(p<0.05)$, this means that there is a significant relationship between age and compliance with hypertensive clients in undergoing treatment at Talang Health Center, Solok Regency in 2014. The results of further analysis obtained odds. ratio (OR) 9.889 can be interpreted that any change in the age value either increases or decreases it will trigger a compliance value of $9.8 \mathrm{x}$ fold (Fitrina \& Harysko, 2014).

In contrast to Nurhidayati's research at the UPT Puskesmas (Health Center) Patuk I, Gunungkidul Regency, with the title the factor of Adult Hypertension Patients is More Obedient than the Elderly in Taking Blood Pressure Lowering Drugs in 2018, the result was that respondents were elderly $(56.6 \%)$. There is a relationship between the respondent's age group and the compliance with treatment of hypertension sufferers and the adherence to treatment in the adult age group is higher than the elderly.

Age is the length of life for a person from birth to the time of being interviewed, the higher a person's age, the more mature a person is in thinking and acting. Increasing age can increase the risk of hypertension. Although hypertension can occur at any age, it most commonly affects adults aged 35 years or older. This is due to natural changes in the heart, blood vessels and hormones. However, if these changes are accompanied by other risk factors it can lead to hypertension (Agoes, 2018).

The occurrence of increasing age is a very influential factor, in increasing blood pressure and all cardiovascular risks. Someone over 65 years of age with hypertension has a higher risk than at a younger age, therefore treatment with antihypertensives will be very beneficial (Chasani, 2016). In the elderly, they will generally obey any doctor's or pharmacist's advice considering various reasons, because they are driven by the desire to recover. In addition, in the prolanis program, patients do not need to think about how much it costs to buy drugs. Some elderly patients do not have much activity so they tend to be more obedient in taking medication (Kionowati. et al., 2018).

\section{Effect of Gender on Compliance with Hypertension Patients}

Based on the results of the study showed that there was no effect of gender on compliance with hypertension patients at Mitra Medika General Hospital Medan in 2020, p = 0.215>0.05. This research is in line with Hazwan's research. There were 50 respondents who suffered from hypertension in the working area of the Kintamani I Health Center. Based on gender, it was found that most of the respondents $(56 \%, 0)$ were female. As many as $44.0 \%$ of respondents were male. In this study, it was found that the male gender had a higher ability to take medication than the female (Hazwan \& Pinatih, 2017). The results of this study were also reinforced by research conducted by Kionowati in Kendal Regency in 2017 which found that there was no relationship between gender and compliance with hypertensive patients taking medication (Kionowati. et al., 2018).

Different from Nurhidayati's research at UPT Puskesmas Patuk I, Gunungkidul Regency in 2018, the sex of the respondents was mostly women (61.2\%), adherence to treatment of adult patients $(41.2 \%)$ was higher than the elderly group (29.4\%). There is a relationship between gender and compliance with hypertensive patients. Likewise with Hazwan's research in the Kintamani I Health Center's working area, it was found that the male gender has a higher ability to take medicine than women. In the study, it was found that more men aged $>50$ years had 
hypertension where there was a higher risk of experiencing complications from hypertension, so they were more adherent to taking hypertension drugs (Hazwan \& Pinatih, 2017).

Fitriana's research shows that respondents who suffer from hypertension who are male are more obedient to undergoing treatment than those who are female, because male respondents are more aware of the importance of health, because they have the status of the backbone of the family who must maintain their health, if they are sick then those who are earn a living does not exist. Therefore, the male respondents' awareness arose to undergo treatment (Fitrina \& Harysko, 2014).

Usually, women pay more attention to their health than men. These results are consistent with Saepudin's research in Liberty, which shows that there is no relationship between gender and drug adherence in hypertensive patients. This is because women and men alike have awareness in the use of hypertension drugs (Liberty, 2017). In contrast to the research conducted by Alphonche, gender was associated with treatment adherence in hypertensive patients $(\mathrm{p}=0.044)$. The difference in results occurred because more samples were used (135 people) (Alphonce, 2012).

Women usually tend to be more obedient to following doctor's recommendations than men including the recommendation to regularly take medication because by nature women who want to look beautiful and don't want any defects in their bodies (Smet, 2015). There are a number of physical differences between men and women. Gender differences regarding verbal skills are often not large or even non-existent. However, compared to men, women tend to stand out in the areas of reading skills and achievement in school. Socio-emotional differences can include; men are physically more aggressive and active; women show a stronger interest in relationships, have better self-regulation in behavior and emotions, and are more involved in prosocial behavior (Santrock, 2015).

\section{The Effect of Motivation on Compliance with Hypertension Patients}

Based on the results of the study showed that there was an influence between motivation on compliance with hypertension patients at Mitra Medika General Hospital Medan in 2020, p $=0.029<0.05$. The motivation variable, the value of $\operatorname{Exp}(\mathrm{B}) / \mathrm{OR}=3.339$, means that the elderly with high motivation have a high chance of adherence to hypertension treatment, 3.3 times higher than the elderly with low motivation.

Research conducted by Fartini (2017) at Puskesmas Medan Sunggal in 2017 which examined the factors that influence the compliance of hypertensive patients in the elderly in treatment shows that one of the factors that influence the compliance of hypertensive patients with treatment is the motivational variable. The motivation factor for treatment is the most dominant variable in influencing patient compliance with hypertension among the elderly in treatment (Fartini, 2017). The results of previous research conducted by Rosmalina in the working area of the Guguak Panjang Public Health Center, Bukittinggi City, found that there was a significant relationship between the motivation of hypertensive patients with adherence to treatment (Rosmalina, 2016). The results of Fitrina and Harysko's research at Talang Community Health Center, Solok Regency in 2014 showed that respondents with high motivation $(91.2 \%)$ had compliance and $8.8 \%$ had non-compliance. Respondents with low motivation, there are $25 \%$ ) have compliance and $75 \%$ have non-compliance. After the statistical test was carried out with the chi-square test, it was found that there was a significant relationship between motivation and compliance with hypertensive clients in undergoing treatment recommended by health workers (Fitrina \& Harysko, 2014). 
Motivation is the drive from humans to act or behave. Motivation cannot be separated from the word need, because need is a potential in humans that needs to be responded to or responded to. Responses to these needs are manifested in the form of actions to fulfill these needs and the result is that the person concerned feels or becomes satisfied. If the need has not been responded to, it will always have the potential to reappear until the intended needs are met (Siagian, 2018).

Motivation is a driving force that converts energy in a person into the form of activities to achieve certain goals or a change in energy in a person's person which is characterized by the emergence of effectiveness (feelings) and reactions to achieve goals. The energy change in a person takes the form of a real activity in the form of physical activity. Because a person has a specific goal from his activities, then someone has a firm and strong motivation with all the efforts that can be made to achieve his goals (Uno, 2016).

\section{The Influence of Knowledge on Hypertension Patient Compliance}

Based on the results of the study showed that there was an influence between knowledge on the compliance of hypertensive patients at Mitra Medika General Hospital Medan in 2020, $\mathrm{p}=0.025<0.05$. The knowledge variable has a value of $\operatorname{Exp}(\mathrm{B}) / \mathrm{OR}=3.594$, meaning that the elderly with good knowledge have a high chance of adherence to hypertension treatment by 3.5 times higher than the elderly with poor knowledge.

The results of this study are in line with the research conducted by Mukaromah entitled The Relationship between Knowledge of the Elderly about Prevention of Hypertension with the Diet of the Elderly at the Public Clinic of the Temindung Public Health Center in Samarinda in 2019. The results of the study concluded statistically that there was a relationship between knowledge and adherence to the prevention of hypertension in the elderly (Mukaromah et al., 2017). Based on the results of research conducted by the State entitled The Relationship between Knowledge Levels of Hypertension and Patient Compliance for Blood Pressure Control in 2018, it shows that respondents' knowledge of hypertension, mostly in the moderate category $(46.7 \%)$. The results of bivariate analysis showed that the variable knowledge of hypertension was significantly associated with patient adherence to blood pressure control (Negara \& Jiryantini, 2017).

Knowledge is the result of "knowing" and this occurs after people sense a certain object. Sensing objects through the five human senses, namely sight, hearing. Smell, taste and taste by itself. When the senses produce knowledge, it is strongly influenced by the intensity of perceptual attention to the object. Most of human knowledge is obtained through the eyes and ears (Notoatmodjo, 2015). A person's knowledge of health may be important before health behavior occurs, but the expected health action may not occur unless a person has the motivation to act on the basis of his / her knowledge. In addition, high knowledge does not guarantee a person to have good behavior. This is because in addition to knowledge, there are many factors that influence behavior, including beliefs, values, the availability of health facilities or facilities and the behavior of health workers (Notoatmodjo, 2015).

\section{Effect of Health Facilities on Hypertension Patient Compliance}

Based on the results of the bivariate test analysis, it showed that there was no effect of health facilities on hypertension patient compliance at Mitra Medika General Hospital Medan in 2020, $p=0.215>0.05$. The results of this study are in line with Ardiyantika's research at Posbindu PTM, Sidorejo Geneng Village. It was found that health facilities had no effect on treatment compliance for hypertension sufferers (Ardiyantika, 2019). Likewise, Puspita's 
research at the Gunungpati Public Health Center, Semarang City, found that there was no relationship between health service facilities and adherence to treatment in hypertensive patients (Puspita, 2016).

One of the factors affecting treatment compliance is enabling factors (supporting factors), one of which is the availability of adequate (complete) health facilities. Attitudes and efforts made in dealing with hospital conditions, one of the reasons for not acting because of the incomplete health facilities. Access to health services is the availability of health facilities such as hospitals, clinics, health centers, available health workers and the availability of medicines (Notoatmodjo, 2015).

\section{Effect of Distance on Hypertension Patient Compliance}

Based on the results of the bivariate test analysis showed that there was no effect of distance on the compliance of hypertensive patients at Mitra Medika General Hospital Medan in 2020, $\mathrm{p}=0.215>0.05$. In line with Tisna's research at Puskesmas Pamulang, South Tangerang City, Banten Province, that the perception of the distance from the house to the health center $(\mathrm{p}=0.409)$ did not show a significant relationship (Tisna, 2015). Likewise, Puspita's research at Gunungpati Public Health Center, Semarang City, found that there was no relationship between affordability of access to health services and adherence to treatment in hypertensive patients (velue $=0.104)$ (Puspita, 2016). In contrast to the research conducted by Prayogo at Puskesmas Pamulang, South Tangerang City, it was stated that there was a relationship between access to health services to health facilities and compliance with taking medication (Prayogo, 2013).

Attitudes and efforts made in dealing with sick conditions, one of the reasons for not acting because of the far distance to health facilities. Access to health services is the availability of health facilities (such as hospitals, clinics, health centers), the availability of health workers, and the availability of medicines (Notoatmodjo, 2015). Good health services are health services that can be reached by all people. Access to health services can be seen from the resources and characteristics of health service users. The affordability of access referred to in this study is seen in terms of distance, travel time and ease of transportation to reach health services. the farther the patient's house is from the health service place and the difficulty of transportation, the more frequent it will be related to the regularity of treatment (Kemenkes RI, 2014).

\section{The Effect of Insurance Participation on Compliance with Hypertension Patients}

Based on the results of the study, it shows that there is an effect between insurance participation on hypertension patient compliance at Mitra Medika General Hospital Medan in $2020, \mathrm{p}=0.022<0.05$. The insurance participation variable has a value of Exp (B) $/ \mathrm{OR}=$ 5.667 , meaning that the elderly who participate in insurance have a high chance of adherence to hypertension treatment, which is 5.6 times higher than the elderly who do not participate in insurance. Insurance participation is the most dominant factor affecting hypertension patient compliance.

This study is in line with Sari's research which showed that patients who did not participate in the health insurance program had an increased risk of failure to control blood pressure by 1.23-2.89 times compared to patients who participated in the health insurance program. It is concluded that participation in the national health insurance program is very important so that patients can receive regular hypertension treatment and blood pressure control can be achieved (Sari \& Listya, 2016). Health insurance is insurance whose object is life, the purpose of health 
insurance is to transfer the risk of illness costs from the insured (owner) to the insurer. So that the obligation of the insurer is to provide health care services (costs) to the insured when he is sick (Law No.40 / 2014). The availability or participation of health insurance plays a role as a factor in patient treatment compliance, with the existence of health insurance it is easier in terms of financing so that it is more compliant compared to those who do not have health insurance (Liberty, 2017).

In Indonesia, health insurance has been promoted by the government since January 1, 2014 with several name changes until now it is referred to as BPJS. Until now, some people have used BPJS as insurance in the utilization of health services both at health centers and in hospitals. As in Cho \& Kim's research, the majority already have health insurance and are aware of the benefits of its use, this is also supported by the economic level and knowledge of the Korean people who are more advanced than the people in Indonesia (Cho \& Kim, 2014). It is known that the cost factor has an important role to influence adherence to hypertensive patients in taking medication. The existence of this relief in terms of financing allows patients to remain obedient to undergo treatment regularly even without health insurance participation (Alphonce, 2012).

\section{Effect of Family Support on Hypertension Patient Compliance}

Based on the results of the study, it shows that there is an influence between family support on compliance with hypertension patients at Mitra Medika Medan General Hospital in 2020, p $=0.046<0.05$. The family support variable has a value of $\operatorname{Exp}(\mathrm{B}) / \mathrm{OR}=3.471$, meaning that the elderly whose families are supportive, have a high chance of adherence to hypertension treatment by 3.4 times higher than the elderly whose families are less supportive.

This research is in line with the research conducted by Fartini with the title Factors Affecting the Compliance of Hypertension Patients in the Elderly in Treatment at the Medan Sunggal Public Health Center in 2017 that there is an influence of family support factors on hypertension patient compliance with the elderly in treatment (Fartini, 2017). Furthermore, Dewi's research entitled Relationship between Family Support and Treatment Compliance in Patients with Hypertension at Dau Public Health Center, Malang Regency in 2018 found that there was a relationship between family support and treatment compliance in patients with hypertension (Dewi et al., 2018).

Family, namely a very close person consisting of several, namely husband or head of the family, wife, and children and even parents who live in one house (Andarmoyo, 2015). Family social support refers to social supports that are seen by family members as something that can be accessed / provided for the family (social support is biased or not used, but family members perceive that supportive people are always ready to provide help and assistance if needed). Social support consists of verbal and / or non-verbal information or advice, real help or action provided by social familiarity or obtained because of their presence and has emotional benefits or behavioral effects on the recipient (Friedman, 2015).

The biggest problem with hypertension sufferers is the patient's non-compliance with the advice given by the doctor, for example requiring patient discipline to abstain in their food, regular exercise, adequate rest and not forgetting to take medication according to the doctor's instructions. Family support is needed so that people with hypertension can comply with the recommendations of health workers so that blood pressure remains normal or under control (Hanata, 2017). Adherence to hypertension treatment is an important factor in the continued health and well-being of hypertensive patients. Adherence and adherence are prerequisites for 
the effectiveness of hypertension therapy and the greatest potential for improved hypertension control lies in improving the patient's behavior. The role of the closest people, especially family members with hypertension sufferers, has a significant impact on controlling blood pressure for people with hypertension (Annisa et al., 2013).

\section{The Influence of Health Care Workers' Support on Hypertension Patient Compliance}

Based on the results of research, multivariate analysis showed that there was no effect of support from health workers on hypertension patient compliance at Mitra Medika General Hospital Medan in 2020, $p=0.697>0.05$. In contrast to the research conducted by Fartini at the Medan Sunggal Puskesmas in 2017, it was shown that the factor of support for health workers in hypertensive patients had an effect on the compliance of hypertensive patients with the elderly in treatment (Fartini, 2017). Likewise research conducted by Puspita where the results of the study concluded that the role of health workers $(p=0.000)$, had an effect on the compliance of hypertensive patients (Puspita, 2016).

Hypertension is a disease that cannot be cured but can only be controlled so that someone who has hypertension to be able to control blood pressure within normal limits requires regular control, a low salt diet and other recommendations according to a doctor's prescription. This means that people with hypertension inevitably have to leave their old lifestyle and adjust to a new lifestyle in accordance with the advice of a health worker (doctor) to keep their blood pressure normal. The role of health workers is very important to provide explanations for hypertension sufferers (Hanata, 2017).

Support from health workers is needed by people with hypertension, because from health workers most information about disease and treatment is obtained. Besides providing information, support from health workers is also in the form of good services and attitudes during the service process. Support from health professionals is another factor that can influence compliance behavior. Good service from officers can lead to positive behavior. The behavior of friendly health workers who immediately treats the patient without waiting long and the patient is given an explanation of the drugs given and the importance of taking regular medication will encourage sufferers to be obedient (Smet, 2015).

\section{Research Implications}

Health workers can provide information about the types of food consumed and the types of foods that should be avoided for people with hypertension so that blood pressure does not increase. Compliance with hypertensive patients following the recommendations of health workers can have an impact on blood pressure control which in turn has an impact on the reproductive health of the elderly and their families by providing support to elderly people with hypertension to be obedient to check or control blood pressure regularly, take antihypertensive drugs regularly, go on a diet low in salt, and do regular exercise. Families can remind, accompany, and supervise the daily activities of the elderly so that they have high compliance in controlling blood pressure and can remind each other and find out information about hypertension and its impact on the health of the elderly.

\section{Research Limitations}

The object of this research is the elderly and most of them have a background in basic education (SD/SMP) so that when conducting data dissemination or conducting interviews, the researcher does it slowly so that the research time becomes longer than if it is researching young people. This research was conducted during the Covid-19 pandemic, so researchers must 
do it carefully. To overcome this, the researchers applied health protocols when collecting data (distributing questionnaires and interviews) using masks, washing hands before and after carrying out activities, and maintaining a distance from respondents / informants (social distancing).

\section{Conclusion}

Based on the results of research that has been carried out and presented in the discussion in the previous chapter, it can be concluded that age does not affect the compliance of hypertensive patients at Mitra Medika General Hospital Medan in 2020, p = 0.802. And the qualitative results state that informants who are less obedient in treatment because they have good family motivation and support. Gender has no effect on the compliance of hypertensive patients at Mitra Medika General Hospital Medan in 2020, $p=0.215$ And the qualitative results state that informants who have the sex are less obedient in treatment because they have motivation to seek treatment. Knowledge affects the compliance of hypertensive patients at Mitra Medika General Hospital Medan in 2020, $p=0.025$. Having good knowledge of not being obedient to treatment can be influenced by other factors, namely motivation, family support and qualitative results suggesting that informants who have good knowledge do not comply with treatment because they are tired of taking medication and the perception that they are cured. Motivation affects the compliance of hypertensive patients at Mitra Medika General Hospital Medan in 2020, $\mathrm{p}=0.029$. And the qualitative results of informants who have good motivation obey the treatment. Motivation to want to recover provides encouragement to seek treatment adherently in taking medication, and return to the hospital for control.

\section{References}

Agoes, A. (2018). Penyakit di Usia Tua. Buku Kedokteran EGC.

Alphonce, A. (2012). Factors Afecting Treatment Compliance Among Hypertension Patients In Three District Hospital - Dar Es Salaam. Dar Es Salaam: Universitas Muhimbili.

Analisadaily. (2018). Selama 2017, Penyakit Tidak Menular Menurun. Analisadaily.Com.

Andarmoyo, S. (2015). Keperawatan Keluarga Konsep Teori, Proses dan Praktik. Keperawatan. Graha ilmu.

Annisa, A. F. N., Wahiddudin, \& Ansar, J. (2013). Faktor Yang Berhubungan Dengan Kepatuhan Berobat Hipertensi Pada Lansia di Puskesmas Pattingalloang Kota Makassar. Universitas Hasanuddin Makassar.

Ardiyantika, N. N. (2019). Faktor-Faktor Yang Berhubungan Dengan Kepatuhan Berobat Penderita Hipertensi Di Posbindu PTM Desa Sidorejo Kecamatan Geneng Kabupaten Ngawi. Program Studi S1 Kesehatan Masyarakat STIKES Bhakti Husada Mulia Madiun.

Arumwardhani, A. (2017). Psikologi Kesehatan. Galangpress.

Chasani, S. (2016). Candesartan Delays Disease Progression in Patient with High Normal Blood Pressure (Prehypertension). Universitas Diponegoro.

Cho, S.-J., \& Kim, J. (2014). Factors Associated With Nonadherence to Antihypertensive Medication. Nursing \& Health Sciences, 16(4), 461-467.

Dahlan, M. S. (2011). Statistik untuk kedokteran dan kesehatan. Penerbit Salemba. 
Dewi, A. R., Wiyono, J., \& Candrawati, E. (2018). Hubungan Dukungan Keluarga Dengan Kepatuhan Berobat Pada Pasien Penderita Hipertensi di Puskesmas Dau Kabupaten Malang Tahun 2018. Nursing News, 3(1), 459-469.

Fartini, E. (2017). Faktor-faktor Yang Memengaruhi Kepatuhan Pasien Hipertensi Pada Lansia Dalam Berobat Di Puskesmas Medan Sunggal Tahun 2017.

Fitrina, Y., \& Harysko, R. O. (2014). Hubungan Karakteristik dan Motivasi Pasien Hipertensi Terhadap Kepatuhan Dalam Menjalani Pengobatan di Puskesmas Talang Kabupaten Solok Tahun 2014. Program Studi Ilmu Keperawatan STIKes YARSI SUMBAR Bukittinggi.

Friedman, M. (2015). Buku Ajar Keperawatan Keluarga Riset, Teori, \& Praktik. Penerbit Buku Kedokteran EGC.

Hairunisa. (2014). Hubungan Tingkat Kepatuhan Minum Obat Dan Diet Dengan Tekanan Darah Terkontrol Pada Penderita Hipertensi Lansia Di Wilayah Kerja Puskesmas Perumnas I Kecamatan Pontianak Barat. Program Studi Pendidikan Dokter Fakultas Kedokteran Universitas Tanjungpura Pontianak.

Hanata. (2017). Pola Hidup Sehat untuk Lansia (Cetakan 2). Toga Putra.

Hazwan, A., \& Pinatih, G. N. I. (2017). Gambaran Karakteristik Penderita Hipertensi dan Tingkat Kepatuhan Minum Obat di Wilayah Kerja Puskesmas Kintamani I. Intisari Sains Medis, 8(2), 130-134.

Hidayat, A. A. A. (2016). Metode Penelitian Keperawatan dan Teknik Analisis Data (Cetakan 3). Salemba Medika.

Kabo, P. (2018). Bagaimana Menggunakan Obat-obat Kardiovaskuler Secara Rasional. Balai Penerbit FKUI.

Kemenkes RI. (2014). Pusat Data dan Informasi Kementerian Kesehatan RI. Pusat Data dan Informasi Kementerian Kesehatan RI. https://doi.org/10.1177/109019817400200403

Khanam, M. A. (2014). Hypertension: Adherence to Treatment in Rural Bangladesh - Findings from a Population-Based Study. Global Health Action, 10(7), 864-869.

Kionowati., Mediastani, E., \& Septiana, R. (2018). Hubungan Karakteristik Pasien Hipertensi terhadap Kepatuhan Minum Obat di Dokter Keluarga Kabupaten Kendal. Jurnal Farmasetis, 7(1), 6-11. https://doi.org/2252-9721

Liberty, I. A. (2017). Determinan Kepatuhan Berobat Pasien Hipertensi Pada Fasilitas Kesehatan Tingkat I. Jurnal Penelitian Dan Pengembangan Pelayanan Kesehatan, $1(1), 58-65$.

Mukaromah, S., Hartati, M. S., \& Maimunah, S. (2017). Hubungan Pengetahuan Lansia Tentang Pencegahan Hipertensi Dengan Pola Makan Lansia. STIKES Wiyata Husada Samarinda.

Nasution, R. E. P. (2017). Pedoman Hipertensi ACC/AHA 2017. Whitecoathunter.Com.

Negara, I. G. N. M. K., \& Jiryantini, N. W. S. (2017). Hubungan Tingkat Pengetahuan Tentang Hipertensi Terhadap Kepatuhan Pasien Untuk Kontrol Tekanan Darah (pp. 73-77). Institut Teknologi dan Kesehatan Bali.

Niven, N. (2014). Psikologi Kesehatan Pengantar untuk Perawat dan Profesi Lain. Penerbit 


\section{Buku Kedokteran EGC.}

Notoatmodjo, S. (2015). Ilmu Perilaku Kesehatan. Rineka cipta.

Notoatmodjo, S. (2016). Promosi Kesehatan dan Ilmu Perilaku (Edisi 4). Rineka Cipta.

Nurhidayati, I., Aniswari, A. Y., Sulistyowati, A. D., \& Sutaryono, S. (2018). Penderita Hipertensi Dewasa Lebih Patuh daripada Lansia dalam Minum Obat Penurun Tekanan Darah. 13, 4-8.

Prayogo, A. H. E. (2013). Faktor faktor yang mempengaruhi kepatuhan minum obat anti tuberkuosis pada pasien tuberkulosis paru di Puskesmas Pamulang Kota Tangerang Selatan. Universitas Islam Negeri Syarif Hidayatullah.

Purnawan, I. N. (2015). Kepatuhan Berobat Penderita Hipertensi di Wilayah Kerja Puskesmas Payangan Kabupaten Gianyar. Jurnal Kesehatan Terpadu, 3(1), 15-21.

Puspita, E. (2016). Faktor-faktor yang Berhubungan dengan Kepatuhan Penderita Hipertensi dalam Menjalani Pengobatan (Studi Kasus di Puskesmas Gunungpati Kota Semarang). Jurusan Ilmu Kesehatan Masyarakat Fakultas Ilmu Keolahragaan Universitas Negeri Semarang.

Rosmalina. (2016). Hubungan Motivasi Pasien Hipertensi dengan Kepatuhan dalam menjalani pengobatan di Wilayah Kerja Puskesmas Guguak Panjang Kota Bukittinggi. STIKes YARSI SUMBAR Bukittinggi.

RSU Mitra Medika. (2020). Data Kunjungan Pasien Hipertensi di RSU Mitra Medika Medan.

Santrock, J. W. (2015). Life Span Development: Perkembangan Masa Hidup. Erlangga.

Sari, D. P., \& Listya, M. T. (2016). Pengaruh Keikutsertaan Pasien pada Program Jaminan Kesehatan terhadap Keberhasilan Kontrol Tekanan Darah pada Penderita Hipertensi. EJKI, 4(2), 125-129.

Siagian, S. P. (2018). Teori Motivasi dan Aplikasinya. Rineka Cipta.

Smet, B. (2015). Psikologi Kesehatan. Grasindo.

Sugiyono. (2017). Metode penelitian pendekatan kuantitatif, kualitatif, dan RND (Cetakan 7). Alfabeta.

Sutanto. (2016). Cekal Penyakit Modern Hipertensi, Stroke, Jantung, Kolesterol dan Diabetes. Andi Offset.

Suyanto, B. (2015). Metode Penelitian Sosial: Bergabai Alternatif Pendekatan (Cetakan 3). Prenada Media.

Tisna, N. (2015). Faktor-faktor yang Berhubungan dengan Tingkat Kepatuhan Pasien dalam Minum Obat Antihipertensi di Puskesmas Pamulang Kota Tangerang Selatan Provinsi Banten. Universitas Islam Negeri Syarif Hidayatullah.

Uno, H. B. (2016). Teori Motivasi dan Pengukurannya. Bumi Aksara.

WHO. (2017). Expert Consultation on Diet, Nutrition and The Prevention Of Chronic Diseases. World Health Organization.

WHO. (2018). A Global Brief On Hypertension Silent killer, Global Public Healt Crisis. Menara Ilmu, XXI. 
